\title{
The Mediator. Richard III and Macbeth in Einar MárGudmundsson's Novel Angels of the Universe
}

\author{
Jørgen SteenVeisland \\ University of Gdansk, Gdansk, Poland
}

\begin{abstract}
Gudmundsson's Angels of the Universe (Englaralheimsins, 1993) stages a poetic psychodrama weaving Shakespeare's characters Richard III and Macbeth into the lives of the first-person narrator Paul and his friend Viktor who are undergoing intensive drug treatment at the Klepp hospital in Reykjavik. Viktor starts impersonating Richard III prior to the treatment at Klepp. While enrolled at an English university he assumes the physical and mental guise of Richard, memorizing whole scenes from the play and speaking lines out loud. At some point his perfect English shifts to perfect German as he merges Richard III with Adolf Hitler in his mind. Viktor thus turns the two despots into what Rene Girard in his work Deceit, Desire and the Novel calls the mediator. Girard explores “triangular” desire in Cervantes' knight-errant Don Quixote whose mediator Amadis chooses the objects of the knight's desire. With Dostoyevsky external mediation becomes internal mediation whose main features are impotence and alienation. Viktor exhibits these symptoms as a negative, inverted form of the mediator has usurped his personality while relegating the objects of his desire to the background. There are no objects any more. He is alone. The article aims to disclose the complex cultural and sociopsychological reasons for exclusión and to explore the poetic dimensión of the novel, indicating thst poetry is capable of transcending the limits imposed by society.
\end{abstract}

Keywords: impersonation, psychiatric treatment, exclusión, loneliness, poetry

\section{Introduction}

The narrator Paul quotes significant passages from Macbeth: "Life's but a walking shadow, a poor player,/That struts and frets his hour upon the stage,/; and: "Canst thou not minister to a mind diseas'd/" (Gudmundsson, 1993, p. 38). The patients at Klepp are walking shadows; yet they are also angels of the universe. While Viktor's mind puts into play an inverted form of the mediator, Paul foregrounds his girlfriend Dagny, turning her into the mediating force of the poetry that informs the narrative: "She is sitting beside the ocean, waiting to see my window reflected in the waves. When I open it, she crawls in and stands on the floor in front of me" (Gudmundsson, 1993, p. 78). Light is ubiquitous in the novel; even the slush in the winter streets "twinkles". The answer to the question "Canst thou not minister" is submerged yet manifested in the poetic fabric of the narrative.

Jørgen SteenVeisland, Associate Professor of Scandinavian literature, the University of Gdansk; Visiting Professor at the University of California-Berkeley; the University of Caen, France; and Fudan University, Shanghai, China. 


\section{The Aesthetics of Schizophrenia}

The opening page of Einar Gudmundsson’s Angels of the Universe (Englaralheimsins; 1993) sets the stage, paradoxically, for the grounding of meaning in the groundless by engaging in a poetics of indeterminacy. Greyness and fog prevail close by the sea where Klepp, the psychiatric hospital in Reykjavik, stands "like a gigantic palace” (Gudmundsson, 1993, p. 3). After having been admitted to Klepp the first-person narrator, Paul, recalls an incident from when he was a little boy. He spots a middle-aged man who is holding his twenty-year old son by the shoulder and pushing him along. Paul asks the man, "Where are you taking him?”, to which the man spits out: “Off to Klepp!”. The narrator’s description of the scene is significant:

I could see his forehead glistening with moisture. He wore an expression as if he were gnashing his teeth. Behind the greyness of his eyes, flames were blazing.

The they vanished into the fog.

It swallowed them just like in the mysterious folk tales my mother used to tell me at bedtime the words: "Once upon a time, long, long ago ...” (loc. cit.) (Gudmundsson, 1993, p. 3)

The primeval Father, Law-giver, manifests himself here as a form of psychic archetype ordering the disorderly, ordaining and instigating an impossible psychological, moral and aesthetic determination of the indeterminate. The father's eyes are grey, his hair colorless, yet his eyes are blazing with flames. The powerfully loaded image of the father as originator of a dialectical discourse that would divide the mind and the world in two denotes the splitting of the universe of the novel in two, which I would designate as an effort to have consciousness and identity emerge from a subconscious state, thus producing signification and commencing a cycle of meaning; yet, by a deft rhetorical maneuver indeterminacy is preserved, even enhanced by the symbolic contrast between the colorlessness of the father's eyes and hair and the blazing flames emanating from his face: illumination in the midst of a timeless fog and a ubiquitous greyness. The timelessness of the folk-tale phrase “Once upon a time, long, long ago ..." epitomizes the impossibility of situating meaning in the universe and indicates, ominously, the tragic mistake connected with the forceful imposition of signification. The effect of that imposition is schizophrenia, institutionalized in Klepp.

However, there is a positive, supplementary effect accompanying the splitting of the mind and the world: An aesthetic counteracting that turns the illness of schizophrenia into a vehicle for poetic discovery and illumination. The blazing flames emanating from the father's eyes symbolize a two-fold illumination: the illumination of fury and madness as well as the illumination of poetry in the novel's discourse. Paradoxically, dialectics is overcome and vanquished by its own energy as mental, sociopolitical and moral division are sublimated, creating what Herbert Marcuse in The Aesthetic Dimension refers to as a heightened subjectivity, extreme perhaps in its response to alienation but nevertheless constitutive of a new poetics, indeterminate and discontinuous.

Paul is born on the day Iceland joined NATO. Massive demonstrations against the alliance take place in Reykjavik. The splitting of the mind and the political divisiveness of the world at large form an intricate, insoluble reality encompassing everyone and everything in the narrative. The narrator, typically and significantly, poses the question whether the Icelandic nation was "under a special curse, laid by guardian spirits and the maid of the mountains?” (Gudmundsson, 1993, p. 12). Folklore once again emerges as an underlying spiritual force informing modern politics and the mental state of the narrator-protagonist. The father with the blazing eyes is at 
one and the same time attached to and detached from the original folklore, representing as he does a deviated form of the timeless culture of Iceland. That timelessness is captured and reinstated in the poetic discourse of Paul's narrative when he asks:

Have you been, bright swan, to reality's empty shores, where the angels dance ...?

Old ships sail up to you in a dream and the fog sits down on the sand beside you.

But the lights can be seen in the palace all the same, a yellow-grey gleam, to the accompaniment of the ocean. (Gudmundsson, 1993, p. 20)

A schizophrenic color scheme: the gleam of the palace, Klepp, is yellow and grey and the same time, as color and light emerge from the obliterating greyness. The greyness of the father's eyes and the flames blazing out of them are now beginning to form an aesthetic duality, or dualism even, which Paul proceeds to transcend in his own poetic scheme. Paul's creative activity begins with a powerful impression received upon observing a painting by the local artist Bergsteinn, figuring the beach, the ocean and Klepp:

Bergsteinn was finishing colouring the the psychiatric hospital roof red when he looked at me.

'Look, Paul,' he said. 'I've taken the land and the sea, the sky and the birds and that hospital there, and put them all into this little picture.’

I looked at the landscape, then back at the painting. Bergsteinn was quite right: the canvas had absorbed everything.

'Well, Paul,' he said. 'Don't you think that's clever of me?'

'Yes,' I said, staring dumbfounded at these two worlds, the reality in the reality and the reality in the picture. (Gudmundssson, 1993, p. 25)

Bergsteinn's artistic gesture equalizes two realities. The outside reality is transferred to the picture where it becomes an inside reality. Paul's dumbfounded response is symptomatic of the radical erasure of difference, distance and of reflection itself that occurs in an aesthetic act defying reason and logic.

Later Paul recalls the conversation with Bergsteinn, at a time when he has become convinced that he is van Gogh reincarnate. Here Paul is covered with paint, signifying the schizophrenic turning inside-out of the mind. The process is driven forward by the artistic medium itself, paint, which covers Paul's body and colors the world. Once again, reality is transferred as reflection is erased. Simultaneously, the father and Icelandic folklore hold sway. In the contemporary setting they deviate in the protagonist's mind; but this deviation is logical: it accelerates a poetic process whereby seeming opposites are unified and cancelled out, as when Paul writes:

Still the shadow creeps over the houses.

Still the darkness floats along the rootless channels of the air.

Outside, the slush twinkles.

The moonlight gleams.

Beneath the starry glory of the world, the lampposts stand alone. (Gudmundsson, 1993, p. 35)

"The slush twinkles". The poetry accomplishes a unique transcendence of the split mind and the split world, schizophrenia healed by re-directing and sublimating its own energy. Similarly, when Paul loses his girlfriend 
Dagny he creates a poetic image that recreates her presence, endowing her image with the magic of a folklore figure in his mind's eye:

She is sitting beside the ocean, waiting to see my window reflected in the waves. When I open it, she crawls in and stands on the floor in front of me.

I sense the aroma of birch from her breasts and the scent of flowers and summer that buds like heather in her eyes.

For an instant, her blood races through my veins while the fires from old wines blaze beneath my heels.

Then I stand naked and alone. (Gudmundsson, 1993, p. 78)

The woman coming in from the outside is preconditioned upon the opening of the window and upon the erasing of reflection. The window as a mirror reflected in the waves is an affirmation of the artwork's ability to reflect; yet it is also a denial of that ability. For reflection stands between Paul, the loving subject, and the woman, his beloved. The window as a powerful barrier occurs in Emily Bronte's Wuthering Heights, of course, in the scene where Cathy implores Heathcliff to let her in. The barrier of reflection, the "prison-house of language", as Wordsworth calls it, prompts Paul to write a story where "I shall jump from one topic to the next, completely as fancy takes me, supported by neither literary formulae nor prior psychiatric examination.” (Gudmundsson, 1993, p. 109)

\section{Shakespeare and the Purloined Letter}

In Revolution in Poetic language, Julia Kristeva offers the following interpretation of the signifying process:

Once the break instituting the semiotic process has been established, what we have called the semiotic chora acquires a more precise status. Although originally a precondition of the symbolic, the semiotic functions within signifying practices as the result of a transgression of the symbolic. (Kristeva, 1984, p. 68)

Applying Kristeva's concept of the semiotic chora to the inmates at Klepp, in particular Paul's friend Viktor who, like Paul himself, has been diagnosed with schizophrenia, I now proceed to describe Viktor's impersonations of Shakespeare's characters Macbeth and Richard III and, following those, his impersonation of and identification with Adolf Hitler — whom he calls "Addie" — as semiotic transgressions of the symbolic. These transgressions assume the form of what Rene Girard calls the mediator in his discussion of Cervantes' Don Quixote about whom Girard says:

... He no longer chooses the objects of his own desire-Amadis must choose for him. The disciple pursues objects which are determined for him, by the model of all chivalry. We shall call this model the mediator of desire. (Girard, 1965, pp. 1-2)

While a student in London Viktor begins to drink heavily and also starts taking drugs. He learns all of Hamlet by heart and goes on to cite Macbeth and Richard III. He is especially obsessed with the character of Richard and begins to identify with him. He becomes Richard. However, unlike Don Quixote who directs his desire outward towards objects and persons in the world, Viktor has progressed to a state of mind where mediation has become internal. Like Paul, Viktor is alone. The internalizing of the mediator is accelerated by a metamorphosis of the self into an Other, or rather, many others. Once again, inside becomes outside in a 
dream-like process whereby several non-substantial, non-essential selves in the guise of Shakespeare's characters are posited. The Other as an essential dialectical counterpart of the Self is perforated by the semiotic chora as Viktor's voice impersonates Richard III. Viktor becomes testimony to Macbeth (as quoted by Paul):

Life's but a walking shadow; a poor player,/That struts and frets his hour upon the stage,/And then is heard no more: it is a tale/Told by an idiot, full of sound and fury,/signifying nothing. (Gudmundsson, 1993, p. 38)

Then Adolf Hitler arrives on the scene:

Viktor had come across some gramophone recordings of his speeches and listened to them in raptures.

Viktor could feel characters like Richard III merging into Hitler's temperament and he even started giving Hitlerian speeches of his own. (Gudmundsson, 1993, p. 135)

Totalitarian discourse is, at one and the same time, the ultimate affirmation of the semiotic and a negation of it. The negation of the chora occurs as an absurd (and dangerous!) search for symbolization and representation. Interestingly, though, Viktor's lapse from Shakespeare's drama into reality, a fascist reality, demonstrates once again the turning inside-out of the schizophrenic mind. What is more, the extreme pole of the projection of a mental state on to reality, and Viktor identifying with Hitler, at least rhetorically, indicates the fallacy of institutionalization. The psychiatric hospital Klepp signifies kleptomania, a purloining of the minds of the patients. The purloining consists in using drug treatment, often in the form of overdoses, to 'minister to a mind diseas'd'. As Jacques Lacan points out in his "Seminar on the Purloined Letter" where he discusses Edgar Allan Poe's tale, the message in the stolen letter from the queen is spotted by Poe's detective when he sees it stuck on a rack turned inside-out, i.e., with the text appearing on the outside. The en-veloped message has been de-veloped. Yet it remains hidden. Its meaning is not revealed. The symbolic is punctuated by the semiotic. Meaning is transgressed.

Paul ends up committing suicide. However, he envisions a rebirth:

No, I am not dead.

I've gone to sea. I am sailing the blue sea in the mansions of the father. The father hauls in the nets. We reach the shore loaded down with our catch. (Gudmundsson, 1993, p.164)

The son is reconciled with the father. The catch hauled in is the richness and fulness experienced when reflection and representation are erased.

\section{Conclusion}

The poetic dimensión signifies and embodies a radical transcendence in Gudmundsson's novel. Rather than being a form of escape from intolerable conditions, exemplified by unfulfilled and unrequited love, by enforced imprisonment in the psychiatric hospital and by a culturally motivated aesthetic dualism, poetry and, indeed, art, in this case painting, opens a window to an other world, a supernatural world as it were. The window to the supernatural world is the médium of a metaphysically oriented poetics guided by the artistic imagination and serving as a forceful compensation for social and moral loss. 


\section{References}

Girard, R. (1965). Deceit, desire and the novel (Y. Freccero, Trans.). Baltimore and London: The Johns Hopkins University Press. Gudmundsson, E. M. (1993). Angels of the universe (B. Scudder, Trans.). New York : St. Martin's Press.

Kristeva, J. (1984). Revolution in Poetic Language (M. Waller, Trans.). New York: Columbia University Press.

Lacan, J. (1966). Seminar on the purloined letter. Ecrits. Paris: Gallimard.

Marcuse, H. (1966). The aesthetic dimension. Boston: Beacon Press. 